\title{
Odd 0 in NMO: isolated Horner syndrome without optic neuritis in a patient with neuromyelitis optica
}

\author{
Fernanda Flores-Alfaro, Sergio A Castillo-Torres, ${ }^{\circledR}$ Alfonso H Gil-Valadez, \\ Romulo Ramírez-Gutiérrez
}

Servicio de Neurología, Hospital Universitario "Dr José Eleuterio González", Universidad Autónoma de Nuevo León, Monterrey, NL, Mexico

\section{Correspondence to} Dr Sergio A Castillo-Torres, sergio.castillotr@uanl.edu.mx

Accepted 1 September 2019

\section{DESCRIPTION}

A previously healthy 28-year-old woman presented 4 days after sudden onset of neck pain radiated to both arms with progressive tetraparesis and bladder dysfunction. On neurological examination, we found normal mental status and higher functions and no meningismus; on cranial nerve examination, we found right ptosis and myosis with preserved pupillary reflexes and mild anhydrosis of the left hemiface, consistent with Horner syndrome (figure 1); we did not find any other cranial nerve dysfunction. On limb examination, we found an asymmetrical disproportionate tetraparesis, worse on right hemibody with lower limb predominance and hyperactive deep tendon reflexes.

MRI of the cervical spine revealed a longitudinally extensive myelopathy (figure 2) and a brain MRI was normal. Cerebrospinal fluid (CSF) analysis revealed a lymphocytic pleocytosis, with elevated protein and normal glucose levels. Infectious causes were discarded with negative PCRs for common bacterial, viral and fungal agents. Oligoclonal bands were negative in both CSF and serum. Anti-AQP4 antibodies were present in both CSF and serum, confirming the diagnosis of neuromyelitis optica spectrum disorder (NMOSD). ${ }^{1} 2$ Normal visual evoked potentials ruled out subclinical optic neuritis. The patient received high-dose pulse methylprednisolone during 5 days with minor improvement; so the five sessions of therapeutic plasmatic exchange were performed. After which, the patient gradually recovered movement against gravity in four limbs, without changes in autonomic dysfunction (Horner syndrome and incontinence). On discharge, the patient was bound to a wheelchair and dependant on a urinary catheter, with a

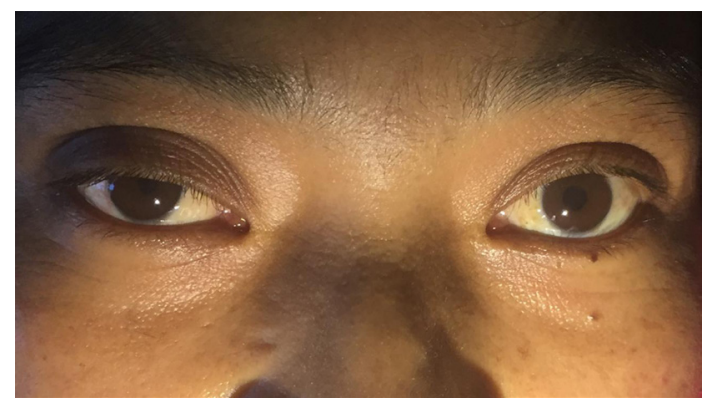

Figure 1 Horner syndrome. We observe right ptosis with an interpalpebral fissure $8 \mathrm{~mm}$ versus $12 \mathrm{~mm}$ and myosis, pupillary size $2.5 \mathrm{~mm}$ versus $4 \mathrm{~mm}$.

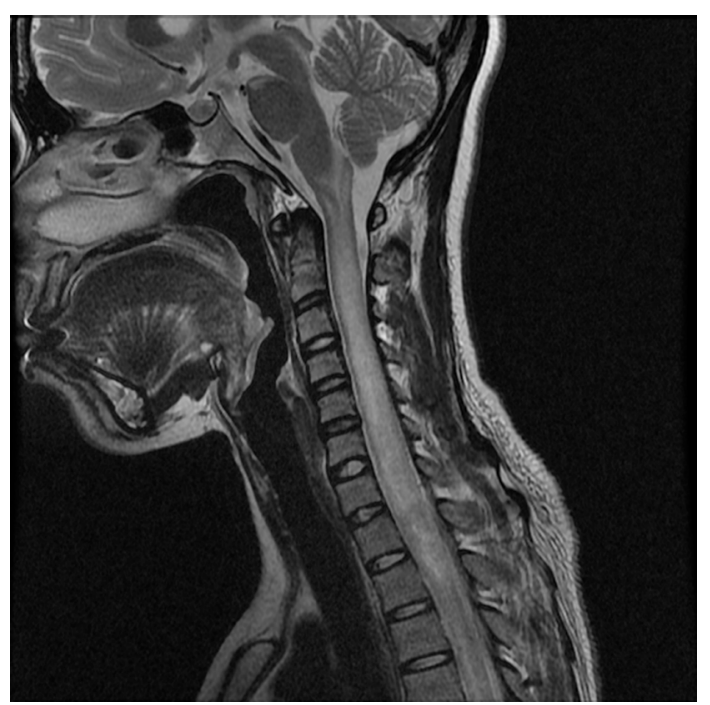

Figure 2 Longitudinally extensive transverse myelitis. On a sagittal T2-weighted MR of the cervical spinal cord, we recognise a longitudinally extensive increase in the signal intensity from the craniocervical junction to $\mathrm{T} 2$, with an expansion of the spinal cord. Incidentally, we observe the rectification of cervical lordosis.

Modified Rankin Scale (mRS) of 5; on follow-up 2 months later, the patient was able to stand and walk unaided, although she was still dependant on a urinary catheter (mRS of 1 ).

Horner syndrome (or oculosympathetic dysfunction) is caused by interruption of the oculosympathetic pathway. In our patient, it was caused by involvement of the second-order neuron in the ciliospinal centre of budge located on the lower cervical-upper thoracic spinal cord, ${ }^{3}$ as demonstrated by the lesion in C7-T1 (figure 2). In NMOSD, the presence of Horner syndrome is uncommon, with only two cases reported in the literature, ${ }^{45}$ ours being the first without overt or silent optic neuritis.

Despite the absence of a clinically overt optic neuritis, the presence of a longitudinally extensive transverse myelitis led us to rule out NMOSD. ${ }^{6}$ Since the discovery of the anti-AQP4 antibody, diagnosis of NMOSD can now be established in the absence of optic neuritis, with one of the other core clinical features: acute myelitis, area postrema, brainstem or diencephalic syndrome, or symptomatic cerebral syndrome with typical brain lesions; and a positive anti-AQP4 antibody assay, with reasonable exclusion of alternative causes. ${ }^{12}$ The current standard of care is based on high-dose 


\section{Learning points}

Lesions of the lower cervical spinal cord can cause Horner syndrome: myosis and ptosis, with variable anhidrosis of the hemiface.

- The absence of optic neuritis does not rule out the presence of neuromyelitis optica spectrum disorder.

- The presence of a longitudinally extensive transverse myelitis warrants exclusion of neuromyelitis optica spectrum disorder-after excluding infectious causes.

steroids, therapeutic plasma exchange or intravenous immune globulin in the acute phase, and immunosuppressor agents for prevention of relapses.

Acknowledgements Author SAC-T would like to thank Mariana Castillo-Torres (Bachelor in Languages for Interpreting and Translation; Monterrey, NL, México) for her assistance on English language style and editing.

Contributors FF-A and SAC-T (clinical neurology residents) were involved in the article conception, design and drafting of the first manuscript. AHG-V (an experienced neuroradiologist) was involved in image interpretation and arrangement for publication, and RR-G (an experienced clinical neurologist) was involved in the examination of the patient and description of clinical findings, and both performed a critical review of the manuscript for intellectually relevant content. All authors agreed on the final version of the manuscript.

Funding The authors have not declared a specific grant for this research from any funding agency in the public, commercial or not-for-profit sectors.

Competing interests None declared.

Patient consent for publication Obtained.

Provenance and peer review Not commissioned; externally peer reviewed.

\section{REFERENCES}

1 Sand IK. Neuromyelitis Optica Spectrum Disorders. Continuum 2016;22:864-96.

2 Fujihara K. Neuromyelitis optica spectrum disorders: still evolving and broadening. Curr Opin Neurol 2019:32:385-94.

3 Campbell WW. The Ocular Motor Nerves. In: DeJong's The Neurologic Examination. 7th edn. Philadelphia, PA: Lippincott Williams \& Wilkins, 2013:179-225.

4 Lovera L, Jay WM, Biller J. Horner Syndrome in a case of Neuromyelitis Optica. Neuroophthalmology 2014;38:78-81.

5 Uludağ IF, Sarıteke A, Öcek L, et al. Neuromyelitis optica presenting with horner syndrome: A case report and review of literature. Mult Scler Relat Disord 2017;14:32-4.

6 Tobin WO, Weinshenker BG, Lucchinetti CF. Longitudinally extensive transverse myelitis. Curr Opin Neurol 2014;27:279-89.

7 Ganesh A. Practice current: How do you treat neuromyelitis optica? Neurol Clin Pract 2017;7:170-8

Copyright 2019 BMJ Publishing Group. All rights reserved. For permission to reuse any of this content visit

https://www.bmj.com/company/products-services/rights-and-licensing/permissions/

BMJ Case Report Fellows may re-use this article for personal use and teaching without any further permission.

Become a Fellow of BMJ Case Reports today and you can:

- Submit as many cases as you like

- Enjoy fast sympathetic peer review and rapid publication of accepted articles

- Access all the published articles

Re-use any of the published material for personal use and teaching without further permission

\section{Customer Service}

If you have any further queries about your subscription, please contact our customer services team on +44 (0) 2071111105 or via email at support@bmj.com.

Visit casereports.bmj.com for more articles like this and to become a Fellow 